\title{
Reconstructing the Past in a changing Landscape. Reflections on the Area of Ephesus and other Sites in Western Asia Minor
}

\author{
Andreas KÜLZER
}

Dedicated to Johannes Nollé on his 65th birthday

Landscapes are in perpetual transformation; change is one of their elementary phenomena. ${ }^{1}$ This is due to several factors, some of them basing on natural causes like climatic changes or changes of soil quality, for example by salinization or lowering of the water table. Human beings provoke other changes, including deforestation, draining of swamps, or river regulation. ${ }^{2}$ Extremely important are the establishment of settlements and the construction of roads and routes for developing a regional or even national communication system. ${ }^{3}$ These are common efforts to transform a natural space into a cultural landscape; ${ }^{4}$ but as a result, one has to notice that the former unified landscape is now structured and divided; its homogeneity is lost.

It is the main task of historical geography to reconstruct the former state of a special landscape, even more to search for regularities of emergence or decline of cultural landscapes in general. ${ }^{5}$ The reconstruction can focus on different aspects, for example the geomorphological situation, but also on historical settlement conditions, the using of agricultural areas or the course of the former road system. There are different methods of reconstruction, scientific approaches like geodesy and geophysics, climatology or pollen analysis, as well as historical or philological approaches like analysis of written sources, archaeological data or onomastic material. ${ }^{6}$ It is necessary to combine the results of all methods if the picture of former days' reality should be trustworthy.

Considering that, it is important to understand the central concepts of landscape and of space. Especially the definition of space is topic of intensive scientific discussion. The ambiguity of the term allows different approaches and various interpretations, in view of the fact that not only geography but also subjects like sociology or literary sciences are affected. ${ }^{7}$ Important and widely accepted is a

* Prof. Dr. Andreas Külzer, Austrian Academy of Sciences, Institute for Medieval Research, Division of Byzantine Research, Hollandstraße 11-13, $4^{\text {th }}$ Floor, 1020 Vienna, Austria (Andreas.Kuelzer@oeaw.ac.at).

${ }^{1}$ An earlier version of this text has been presented at the International Conference "From the Human Body to the Universe... Spatialities of Byzantine Culture", Uppsala University, Sweden, 18-21 May 2017 ("Ephesus and its Hinterland: Reconstructing the Past in a Changing Landscape").

${ }^{2}$ Geyer 2002, 31-45; Telelis 2008, 167-207; Veikou 2012a; Koder 2012, 155-157.

${ }^{3}$ Among others, French 2016a; French 2016b; Külzer 2016, 187-194.

${ }^{4}$ Veikou - Beihammer 2017, 387.

${ }^{5}$ Cf. Kirsten 1987, 1-50; Külzer 2010, 173-184.

${ }^{6}$ Koder 1986, 155-187; Telelis 2004; Koder 2006, 159-183; Koder 2010, 13-22; Popović 2014, 10-17; Külzer, forthcoming a.

${ }^{7}$ Cf. Dünne - Günzel 2006; Cassidy-Welch 2010, 1-4; Ette 2013, especially 49-60; Veikou 2016; Veikou Beihammer 2017, 388-390. 
theory of the French philosopher Henri Lefebvre (1901-1991). ${ }^{8}$ In his opinion, space is more than a mere collection of material realities and persons in a landscape; beyond men and environment space should be understand as a site of ongoing interactions of social relations, as a dynamic process of production inspired by a society. ${ }^{9}$ Yet, each society produces its own individual space, following its own customs and habits. It is exclusively understandable from its respective time and concrete circumstances.

For a proper understanding of his perceptions of space and processes of production of space, Lefebvre developed a tripartite model consisting of the concepts of perceived space, of conceived space, and of lived social space. ${ }^{10}$ The following applies to Byzantium: the buildings erected at that time, the Byzantine houses and fortresses, the basilicas and cross-dome churches, but also the geographical conditions of a special landscape are among the first concept; they are perceptible and part of an everyday spatial practice. Theories of space and spatial statements as mentioned in literary sources belong to the second concept; they are entirely abstract and part of a mental history. The interpretation of these materials allows an approach to the lived reality of the Byzantines, to the third concept. ${ }^{11}$ All three concepts belong together; they are inseparable from each other and present different facets of one image. As a unity, they provide a performing theoretical model for the reconstruction of historical spaces.

However, this model seems to be very general. The Byzantine Empire existed for more than thousand years, and numerous changes took place in this long period. To make the model more precise, one should pay more attention to the factor time and choose smaller time units. The realities of the Early Byzantine Period differ significantly from those of the late Palaeologian period. This applies to different areas, for example to the domain of geographic space: due to geomorphological reasons, countless mountains and islands, coastlines and estuaries changed their form in this millennium. Just to mention the estuaries of the river Meander (Büyük Menderes Nehri) south of modern Samsun dag ${ }^{12}$ or of the river Hermos (Gediz çayı) in the wider hinterland of Smyrna (İzmir). ${ }^{13}$ (See fig. 1). - There were also remarkable changes in the sacral space: from the $6^{\text {th }}$ century onwards, the sacral space in the Byzantine core lands, in Western Anatolia as well as in the Aegean region or in Thrace, was mainly Christian and in some limited parts Jewish; but pagan sacral space, still existing in Late Antiquity, disappeared. ${ }^{14}$ Among numerous examples, I would like to mention here John of Ephesus and the Christianization of thousands of people, the erection of numerous churches and monasteries in the hinterland of Tralleis (Aydin) in the period of Emperor Justinian I. (527-565). ${ }^{15}$ Furthermore, the political space of the Byzantine Empire changed a lot, due to an interplay of conquests and territorial gains on the one hand and partly dramatic losses on the other. Regarding this

\footnotetext{
${ }^{8}$ Lefebvre 1991.

${ }^{9}$ Important also Veikou, forthcoming.

${ }^{10}$ Lefebvre 1991, 38-41, 46, 51, 53 etc.

${ }^{11}$ Cf. Veikou, forthcoming.

${ }^{12}$ Müllenhoff 2005; Ragia 2009, 13-212; Thonemann 2011, 1-49; Brückner e. a. 2017, 877-887.

${ }^{13}$ Doğer 1998, 2, 3, 49, 54, 60, 74, 75, 993 etc.; Meriç 2018, 33-55.

${ }^{14}$ Brown 1995, 27-54; Mitchell 2007, 225-300; Cameron 2012, 58-83.

${ }^{15}$ John of Ephesos, Hist. eccl. III 2, 36-37; Trombley 1985, 329-334; Whitby 1991, 111-112, 130-131; Külzer, forthcoming $b$.
} 
dynamic, the question of the essence of Byzantine space arises: were the Peloponnese or the hinterland of Thessaloniki in the $7^{\text {th }}$ and $8^{\text {th }}$ century or Western Anatolia in the $14^{\text {th }}$ century still included here, regarding the real level of power, the de facto loss of power of the Byzantine Emperor? The answer will surely vary, depending on the personality of the individual researcher...

Transformation of space did not only exist in geographical or geomorphological, in sacred and in political terms, but also on a smaller scale. Just to mention the dislocation of settlements, so often documented through archaeological and literary sources. The old settlement place lost its former importance, while the new one, which was probably ahistorical before, got a new identity. The bishopric Elea for example, situated around 20 kilometers south-east of Pergamum (Bergama) near the modern village of Kazıkbağları at the shore of the Aegean Sea, was dislocated two kilometers further to the north in the late $6^{\text {th }}$ century. The new location, the former uninhabited and dull hills of Püsküllü tepeler, received the tradition and prestige of a bishopric, while the former location found itself largely abandoned. ${ }^{16}$ The later lost its character of a vivid settlement and even its ecclesiastical rank; it became a secular place and transformed to a simple base of some workshops and small factories.

The outcome of social change results in the emergence of new architectural forms and new kinds of settlements, which enriched the variety of forms in the single landscapes. One can think about the appearance of the cross-dome churches after iconoclasm. In most cases smaller and cheaper than the basilicas, people erected them at numerous places all over the Byzantine Empire, on mountain peaks or near the sea. As a result, sacral space increased. Furthermore, one should remember the huge monastic settlements described by Johannes Koder, ${ }^{17}$ which often had the dimension and population of bigger villages or the offshore island settlements, the isles of refuge, mentioned at different occasions by Myrto Veikou and others. ${ }^{18}$ Therefore, the idea of the existence of a Byzantine space as continuum for more than thousand years, as a great abstract noun is more than doubtful. It seems to be necessary for a significant scientific investigation to use the term space only for limited landscapes and working domains on a smaller scale, with a sensible reduction of large time units.

Obviously, the transformation of landscapes and space continued after the end of the Byzantine Empire. In the $18^{\text {th }}, 19^{\text {th }}$, or $20^{\text {th }}$ centuries, it was a common habit for European travelers in Anatolia or in the Balkans, to refer to contemporary local villages as geographic reference points for their archaeological or epigraphical discoveries. Nevertheless, if anyone should look for these mentioned settlements on a modern map, he has to realize that numerous villages do not exist anymore, while others are difficult to identify due to previous renaming measures or an interim dislocation. However, if the former reference points are lost, the identification of the ancient remains connected to them is nearly impossible. Therefore, some places established for a limited time as late antique or Byzantine due to their documented archaeological remains lost their tradition again. They disappeared from common academic knowledge and fall back into historical unawareness due to the technical difficulties of an accurate location of their geographical reference points.

\footnotetext{
${ }^{16}$ Pirson 2014, 340, 355-356; Külzer 2018, 61-62.

${ }^{17}$ Koder 1993/1994.

${ }^{18}$ Hood 1970, 37-45; Veikou 2009; Veikou 2010; Veikou 2012a; Veikou 2012b, Veikou 2013; Veikou, forthcoming.
} 
Scientific identifications of historical sites are elements for structuring a landscape as well. In the year 1881 Heinrich Schliemann identified Lodos burnu, modern Deve burnu at the northwestern end of today's Edremit körfezi, a cape without archaeological remains and therefore an ahistorical place, as Cape Lekton; ${ }^{19}$ thus, the place got a Homeric tradition. Consequently, this place, these stones were the ones commemorated in the writings of the Roman geographer Strabo or the Byzantine authors Constantine VII Porphyrogennētos and John Tzetzēs. ${ }^{20}$ However, some years later scholars recognized that Baba burnu five kilometers further to the northwest was more likely the historical place of Cape Lekton. Therefore, identification changed; the same history was attributed to different stones and another landmark. ${ }^{21}$ The place of Deve burnu turned back after a short period of historicity to insignificance and anonymity, and this happened without any change of its individual geographical character.

In the southern Troad, near the modern village of Kozlu, one can find an impressive ancient settlement place with mighty walls. In the $19^{\text {th }}$ century, people believed it was Gargara, ${ }^{22}$ a well-known place in ancient and medieval times, mentioned as a station in the east of Assos (Behraim Kale) on the Peutinger map and documented as a bishopric until the late $12^{\text {th }}$ century. Here again, identification changed; from 1898 up to now the place is regarded as Lampōneia, ${ }^{23}$ an ancient place without any ecclesiastical tradition. The old walls, remaining identical and unchanged, are now affiliated with other stories and a dissimilar historicity.

After this discussion on different aspects of space, landscape and methods for the correct reconstruction of former day's reality, it is time to switch to the area of Ephesus and its nearer hinterland. Here again, one has to address various problems. One of them is the considerable change of the whole landscape due to alluvial deposits of the river Cayster (Küçük Menderes), which influenced and shaped the entire coastal area (see fig. 2 and 3). ${ }^{24}$ The situation is similar to that of the abovementioned estuaries of the rivers Meander and Hermos. The Cayster created the extended plain in the west of modern Selçuk with its more than 8 kilometers length in the last 2,300 years thanks to its deposits; around 300 B.C. the coastline was just north and west of the Ayasoluk. The Koressos harbor north of the nearby Panayırdağ, already existing in the $8^{\text {th }}$ century B.C. was unusable 700 years later because of sedimentation. ${ }^{25}$ Some decades later, Pliny the Older (23-79) reported that the former island of Syriē was a part of the mainland due to the deposits of the river (V 31,115). ${ }^{26}$ The coastline was at the level of today's Akgöl or Çatalgölü in the early byzantine period; however, the Roman harbor of Ephesus in the west of the Panayırdağ was still in use at that time. Dredging and

\footnotetext{
${ }^{19}$ Schliemann 1881, 17-18, 79.

${ }^{20}$ Strabōn 13,1,6; 13,1,49; Constantine Porphyrogennētos, De thematibus, ed. Pertusi, 83; John Tzetzēs, Lycophronis Alexandra II. Scholia, ed. Scheer, 24, 1170.

${ }^{21}$ Cf. Cook 1973, 190, 238.

${ }^{22}$ Clarke 1888, 298-302; Cook 1973, 253, 255-261; Külzer, forthcoming c.

${ }^{23}$ Cook 1973, 261-264.

${ }^{24}$ Stock e. a. 2013, 58; Steskal 2014, 328-329; Külzer 2018, 51-53. For the headwater and middle course of the river Cayster, see Meriç 2009; Dan 2017, 88-100; Külzer 2017, 195-214, 475-478; Kirbihler 2018, $133-160$.

${ }^{25}$ Scherrer 2007, 347; Steskal 2014, 331-332; Stock e. a. 2014, 38, 56-57; Ladstätter 2016, 233-240, 253-257; Külzer 2018, 50-51.

${ }^{26}$ Brückner e. a. 2017, 887-888, 892.
} 
various construction work were necessary to realize this. A harbor channel was constructed at an early stage to keep the connection with the sea, but because of the ongoing siltation process, it was useable only for small ships already in Late Roman times. ${ }^{27}$ In the middle byzantine period, the seaside run east of the modern village of Zeytinköy, in the late byzantine period at least one kilometer further to the west. ${ }^{28}$ It was constantly necessary to extend the harbor channel that increasingly silted. New roads and routes, small settlements and cultivation areas shaped the alluvial plain; they helped to transform the local natural space into a cultural landscape. Obviously, it is impossible to find larger quantities of ancient ceramics here; even in byzantine times huge parts of the plain did not exist, these regions were still covered with water and belonged to the sea.

The results of these geomorphological studies are useful concerning the localization of toponyms transmitted by literary sources. The harbor of Panormos for example, mentioned by the Roman geographer Strabo $(14,1,20)$, can only be localized in those regions which where coastal areas at the beginning of the Common Era: therefore, wide landscapes in the west of Ephesus are not affected in this context. As mentioned elsewhere, its localization in the north of the river Cayster, at the foot of modern Alaman dağ 1 is unlikely. ${ }^{29}$ The archaeological remains discovered there do definitely not belong to a harbor construction. Instead, a more likely side of Panormos could be the huge harborplace at Çanakgölü south of the Cayster, documented by archaeological and geological data (see fig. 4).$^{30}$ However, some questions need to be answered before the localization is secured, especially concerning the correct assessment of the local ceramic types.

Another harbor is located about 400 meters east of today's coastal line, besides the 10-meter high hill Kumtepe; the area's toponym is Pamucak, ${ }^{31}$ after an adjoining coastal town. The hill was an island in ancient times; later alluvial deposits connected it to the mainland. Since early Byzantine times, there was a huge basilica on the top of the hill. ${ }^{32}$ The church whose name remains unknown served as a pilgrims' destination; a special anchorage enabled the visitors to enter the place. From a small platform, a mighty staircase led upstairs to the basilica. Just a stone's throw away from that place runs the harbor channel with a further port construction. ${ }^{33}$

About two kilometers south of Kumtepe one can find the huge holiday center of Aqua Park, which dominates the surrounding landscape virtually as well as acoustically. Different histories are associated with this place. During construction work of the hotel, many ancient and Byzantine settlement remains were removed or simply destroyed. ${ }^{34}$ These remains were partly interpreted as legacies of the former town of Phygela; for example, the "Topographical Map of Western Asia Minor" published by Alfred Philippson in Gotha in the year 1910 (map 3, scale 1:300,000) was doing so. But more likely, this area was not the place of Phygela; instead, here should be the location of the late

\footnotetext{
${ }^{27}$ Steskal 2014, 333-334; Külzer 2018, 51-52.

${ }^{28}$ Stock e. a. $2013,58$.

${ }^{29}$ Külzer 2018, 56-57 against the theory of Meriç 1985. Furthermore, Stock e. a. 2013, 58, 59, 67.

${ }^{30}$ Hopfgartner 1962/1963, 52; Stock e a. 2013, 59-60, 62-63; Külzer 2018.

${ }^{31}$ Ladstätter e. a. 2014, 2-4; Külzer 2018, 53-54.

${ }^{32}$ Currently ÖAI 2014, 26, 28, 30; ÖAI 2015, 22-23; ÖAI 2016, 27-28.

${ }^{33}$ Stock e. a. 2013, 67; Pfeiffer-Taş 2014, 1095; Külzer 2018, 54.

${ }^{34}$ Pfeiffer-Taş 2014, 1099-1100, Fig. 10-11.
} 
medieval harbor of Ephesus, ${ }^{35}$ a place which according to the German pilgrim Ludolf of Suchem, writing between 1336 and 1341, was located at the front of the seaside, in a distance from about four kilometers from ancient Ephesus. He described the area as an extensive settlement place with numerous residential buildings and (Latin) churches. ${ }^{36}$ The well-preserved wall running up a hill east of Aqua Park and visible even on satellite images, may have been one of the boundaries of this late harbor area. However, I should mention that some scholars correlate Ludolf's description with the above mentioned port near Kumtepe - again we have identical stones connected with various histories, the reconstruction of the landscape's past is the result of single characters and their personal believes...

If the place of Aqua Park is really the location of the late medieval harbor of Ephesus, so one wonders where should be the place of Phygela, ${ }^{37}$ the well-documented town by the sea, where the Byzantine navy gathered twice (in the years 903 and 961) to start the recapture of Crete? A proposed localization at today's Kuşadasi ${ }^{38}$ is much too far to the south. More likely, Phygela was located close to a bay two kilometers south of Aqua Park, near the modern resort of Bayraklidede. This place corresponds best to the descriptions of the literary sources, including the detailed report written by the Latin pilgrim Willibald in the year 721. However, the numerous Byzantine settlement remains, still documented on the shore of the bay in the early $1960 \mathrm{~s},{ }^{39}$ whose analysis would be so useful, are unfortunately completely lost today.

The extended byzantine settlement near Arvalia, 4 kilometers east-northeast of the bay of Bayraklidede, documented in the early 1960s as well, ${ }^{40}$ was also partly identified with Phygela. Other researches localized in the same area Ortygia, a Roman settlement place; the geographer Strabo mentioned its temples and cult buildings $(14,1,20)$. Today Arvalia is associated neither with the first nor with the second tradition. Most people localize Phygela at the mentioned bay; Ortygia seems to be further to the south, near the modern village of Kirazlı or Akçaova, 9 kilometers north of Söke. ${ }^{41}$ Arvalia however did not only lose its various historical traditions, the area lost even its identity. A few years ago the settlement remains were removed, the ground was leveled; and afterwards people established on the former settlement place a training center for the football club Altinordu Futbol Sosyal Girişimi (Altinordu FSG), playing these days in the Second Turkish Division. Only the fragments of ceramics and bricks in the meadows close to the playing fields remind one of the former history of Arvalia. Even a $5^{\text {th }}$ century basilica discovered during construction work in this area in the year 2010 was not preserved, but it is lost again. ${ }^{42}$

The initial statement concerning the perpetual transformation of landscapes is correct in the case of various places in Western Anatolia, in the area of Ephesus and its wider hinterland. The change happened partly due to natural causes, partly due to human beings and their interventions. Some

\footnotetext{
${ }^{35}$ Pfeiffer-Taş 2014, 1088, 1092-1094, 1097-1103; Külzer 2018, 54-56.

${ }^{36}$ Ludolf of Suchem, cap. 18; Pfeiffer-Taş 2014, 1092-1093.

${ }^{37}$ Külzer 2018, 55-56.

${ }^{38}$ Foss 1979, 123; Talbert e. a. 2000, 946 and Map 61.

${ }^{39}$ Hopfgartner 1962/1963, 52, 67-69, Tafel I.

${ }^{40}$ Hopfgartner 1962/1963, 39-51.

${ }^{41}$ Keil 1922-1924, 113-115; Günel 2003, 92-94.

${ }^{42}$ Tok 2017, 373-384, 522-524.
} 
geographical points, clearly determinable in a landscape, are connected with different ideas and historical traditions. The individual valence of these places is not constant but in transformation. Historicity and lack of history alternate with each other. Moreover, what about the above-mentioned theory of space? The idea of the three concepts of perceived space, of conceived space and of lived social space completing each other is applicable for Byzantium. However, the preselected unambiguousness of all concepts does not exist; the factor interpretation is extremely important, especially concerning perceived and conceived space. Moreover, interpretation communicates with subjectivity, and this subjectivity manifests itself in the existence of different localizations. Uniqueness comparable to mathematics or physics is inaccessible. Furthermore, it should be wise to enrich Lefebvre's model with the factor time. The interpretation of space for a whole millennium makes no sense; the use of smaller time units is necessary to get significant results for a correct understanding of historical space, in Western Anatolia or elsewhere in Byzantium.

\section{Bibliography}

Brown 1995

Brückner e. a. 2017

P. Brown, Authority and the Sacred: Aspects of th Christianisation of the Roman World, Cambridge 1995.

H. Brückner - A. Herda - M. Kerschner - M. Müllenhoff - F. Stock, Life cycle of estuarine islands: From the formation to the landlocking of former islands in the environs of Miletos and Ephesos in western Asia Minor (Turkey), Journal of Archaeological Sciences: Reports 12, 2017, 876-894.

Cameron 2012

A. Cameron, The Mediterranean World in Late Antiquity, AD 395700, Abingdon $2^{\text {nd }}$ ed. 2012.

Cassidy-Welch $2010 \quad$ M. Cassidy-Welch, Space and Place in Medieval Contexts, Parergon 27/2, 2010, 1-12.

Clarke 1888

J. T. Clarke, Gargara, Lamponia and Pionia: Towns of the Troad, American Journal of Archaeology 4, 1888, 291-319.

Cook 1973

J. M. Cook, The Troad. An Archaeological and Topographical study, Oxford 1973.

Dan 2017

A. Dan, Die heiligen Kaystros und Kilbis im Byzanz der Makedonischen Zeit: Anmerkungen zum Parisinus Suppl. Gr. 247 Fol. 18r-v, in: A. Külzer - M. St. Popović (eds.), Space, Landscapes and Settlements in Byzantium: Studies in Historical Geography of the Eastern Mediterranean, Presented to Johannes Koder, Vienna-Novi Sad 2017, 75-112, 447-466.

Doğer 1998

E. Doğer, İlk İskanlardan Yunan İşgaline Kadar Menemen ya da Tarhaniyat Tarihi (Including a Map: Eski Menemen Kazası [Geç Kalkolitik - Cumhuriet Dönemi]), İzmir 1998.

Dünne - Günzel 2006 J. Dünne - St. Günzel (Hgg.), Raumtheorie: Grundlagentexte aus Philosophie und Kulturwissenschaften, Frankfurt a.M. 2006.

Ette 2013

O. Ette, Roland Barthes: Landschaften der Theorie, Konstanz 2013.

Foss 1979

C. Foss, Ephesus after Antiquity: A late antique, Byzantine and Turkish City, Cambridge 1979. 
French 2016a

French 2016b

Geyer 2002

Günel 2003

Hood 1970

Hopfgartner 1962/1963

Keil 1922-1924

Kirbihler 2018

Kirsten 1987

Koder 1993/1994

Koder 1986

Koder 2006

Koder 2010
D. H. French, Roman Roads and Milestones of Asia Minor. Vol. 3 Milestones. Fasc. 3.9 An Album of Maps. British Institute at Ankara. Electronic Monograph 9, Ankara 2016.

D. H. French, Roman Roads and Milestones of Asia Minor. Vol. 4 The Roads. Fasc. 4.1 Notes on the Itineraria. British Institute at Ankara (Electronic Monograph 10), Ankara 2016.

B. Geyer, Physical Factors in the Evolution of the Landscape and Land Use, in: A. E. Laiou (ed.), The Economic History of Byzantium. From the Seventh through the Fifteenth Century, I Washington, D.C. 2002, 31-45.

S. Günel, Vorbericht über die Oberflächenbegehungen in den Provinze Aydın und Muğla, Anatolia Antiqua 11, 2003, 75-100.

S. Hood, Isles of Refuge in the Early Byzantine Period, Annual of the British School at Athens 65, 1970, 37-45.

L. Hopfgartner, Die Entdeckung des spätbyzantinischen und genuesischen Ephesos, Studi genuensi 4, 1962/1963, 17-81.

J. Keil, Orthygia, die Geburtsstätte der ephesischen Artemis, Jahreshefte des Österreichischen Archäologischen Institutes 21/22, 19221924, 113-119.

F. Kirbihler, Le Caÿstre et Éphèse. Un exemple d'interaction entre une rivère et ses riverains à l'époque romaine, in: A. Dan - St. Lebreton (eds.), Études des fleuves d'Asie Mineure dans l'Antiquité. II, Arras Cedex 2018, 133-160.

E. Kirsten, Möglichkeiten und Aufgaben der Historischen Geographie des Altertums in der Gegenwart, in: Stuttgarter Kolloquium zur Historischen Geographie des Altertums 1, Geographica Historica 4, Stuttgart 1987, 1-50.

J. Koder, Mönchtum und Kloster als Faktoren der byzantinischen Siedlungsgeographie. Byzantium and the North, Acta Byzantina Fennica 7, 1993-1994, 7-44.

J. Koder, The Urban Character of the Early Byzantine Empire: Some Reflections on a Settlement Geographical Approach to the Topic, in: The $17^{\text {th }}$ International Byzantine Congress. Major Papers, New Rochelle, N.Y. 1986, 155-187.

J. Koder, Land use and settlement: theoretical approaches, in: J. F. Haldon (ed.), General issues in the study of medieval logistics: sources, problems and methodologies, History of Warfare 36, Leiden-Boston 2006, 159-183.

J. Koder, Handelsgüter und Verkehrswege - Problemstellung, Quellenlage, Methoden, in: E. Kislinger - J. Koder - A. Külzer (Hgg.), Handelsgüter und Verkehrswege. Aspekte der Warenversorgung im östlichen Mittelmeerraum, 4. bis 15. Jahrhundert, Österreichische Akademie der Wissenschaften, phil.-hist. Kl., Denkschriften 388, 
Koder 2012

Külzer 2010

Külzer 2016

Külzer 2017

Külzer 2018

Külzer, forthcoming a

Külzer, forthcoming b

Külzer, forthcoming c

Ladstätter e. a. 2014

Ladstätter 2016

Lefebvre 1991
Wien 2010, 13-24.

J. Koder, Regional Networks in Asia Minor during the Middle Byzantine Period (Seventh-Eleventh Centuries). An Approach, in: C. Morrisson (ed.), Trade and Markets in Byzantium, Washington, D.C. 2012, 147-175.

A. Külzer, Möglichkeiten zur Rekonstruktion historischer Landschaften: Die Historische Geographie, in: Ch. Gastgeber - Ch. Glassner - K. Holzner-Tobisch - R. Spreitzer (Hgg.), Fragmente. Der Umgang mit lückenhafter Quellenüberlieferung in der Mittelalterforschung, Österreichische Akademie der Wissenschaften, phil.hist. Kl., Denkschriften 415, Wien 2010, 173-184.

A. Külzer, Von Assos nach Pergamon und Ephesos: Betrachtungen zu den Straßen Westkleinasiens in römischer und byzantinischer Zeit, Asia Minor Studien 78, Bonn 2016 185-204.

A. Külzer, Streifzüge durch das Tal des Kaÿstrios (Küçük Menderes): Historisch-geographische Impressionen aus Westanatolien, in: A. Külzer - M. St. Popović (eds.), Space, Landscapes and Settlements in Byzantium: Studies in Historical Geography of the Eastern Mediterranean, Presented to Johannes Koder, Vienna-Novi Sad 2017, 195-214, 475-478.

A. Külzer, Jenseits von Ephesos: Hafenanlagen an der kleinasiatischen Westküste in spätantiker und byzantinischer Zeit. Gateways: North meets East 3, 2016, [2018], 49-73.

A. Külzer, Herbert Hunger und die Historische Geographie: Geschichte, Gegenwart und Zukunft der Tabula Imperii Byzantini, in: A. Külzer (Hg.), Herbert Hunger und die Wiener Schule der Byzantinistik: Rückblick und Ausblick, Wien.

A. Külzer, Aspekte der Christianisierung der frühbyzantinischen Provinz Asia, Asia Minor Studien.

A. Külzer, Harbours, landing places and communication routes in Northwestern Anatolia: The Gulf of Adramyttium (Edremit körfezi) in late Antiquity and Byzantine times, in: F. Daim - J. PreiserKapeller (eds.), Seasides of Byzantium: harbours and anchorages of a Mediterranean Empire, Mainz.

S. Ladstätter - W. Prochaska - H. Brückner - F. Stock - S. Seren C. Kurtze - N. Gail, Forschungen auf dem Kumtepe. Forschungen in Ephesos. Gesellschaft der Freunde von Ephesos, Information über den Stand der Ausgrabungen 1, 2014, 1-4.

S. Ladstätter, Hafen und Stadt von Ephesos in hellenistischer Zeit, Jahreshefte des Österreichischen Archäologischen Institutes 85, 2016, 233-272.

H. Lefebvre, The Production of Space, translated by D. NicholsonSmith, Maiden-Oxford 1991. Original version: La production de 
Meriç 1985

Meriç 2009

Meriç 2018

Mitchell 2007

Müllenhoff 2005

ÖAI 2014

ÖAI 2015

ÖAI 2016

Pfeiffer-Taş 2014

Pirson 2014

Popović 2014

Ragia 2009

Scherrer 2007 l'espace, Paris 1974

R. Meriç, Zur Lage des ephesischen Außenhafens Panormos, in: Komitee FS Hermann Vetters (Hg.), Lebendige Altertumswissenschaft, Festschrift H. Vetters, Wien 1985, 30-32.

R. Meriç, Das Hinterland von Ephesos. Archäologisch-topographische Forschungen im Kaystros-Tal, Jahreshefte des Österreichischen Archäologischen Institutes, Ergänzungsheft 12, Wien 2009.

R. Meriç, Hermus (Gediz) Valley in Western Turkey: Results of an Archaeological and Historical Survey, İstanbul 2018.

St. Mitchell, A History of the Later Roman Empire, AD 284-641. The Transformation of the Ancient World, Oxford 2007.

M. Müllenhoff, Geoarchäologische, sedimentologische und morphodynamische Untersuchungen im Mündungsgebiet des Büyük Menderes (Mäander), Westtürkei, Marburger Geographische Schriften 141, Marburg 2005.

Wissenschaftlicher Jahresbericht des Österreichischen Arcäologischen Instituts, Wien 2014.

Wissenschaftlicher Jahresbericht des Österreichischen Arcäologischen Instituts, Wien 2015.

Wissenschaftlicher Jahresbericht des Österreichischen Arcäologischen Instituts, Wien 2016.

Ş. Pfeiffer-Taş, Suggestions as to the localization of the harbour of Ayasoluk and the Italian settlement during the Aydınoğulları dynasty from a new perspective, in: M. Sariyannis (ed.), New Trends in Ottoman Studies. Papers presented at the $20^{\text {th }}$ CIÉPO Symposium Rethymno, 27 June - 1 July 2012, Rethymno 2014, 1087-1107.

F. Pirson, Elaia, der (maritime) Satellit Pergamons, in: S. Ladstätter - F. Pirson - Th. Schmidts (Hgg.), Häfen und Hafenstädte im östlichen Mittelmeerraum von der Antike bis in byzantinische Zeit. Neue Entdeckungen und aktuelle Forschungsansätze. Harbors and Harbor Cities in the Eastern Mediterranean from Antiquity to the Byzantine Period: Recent Discoveries and Current Approaches, İstanbul, 30.5. - 1.6. 2011. I. Byzas 19, İstanbul 2014, 339-356.

M. St. Popović, Historische Geographie und Digital Humanities: Eine Fallstudie zum spätbyzantinischen und osmanischen Makedonien, Peleus 61, Wiesbaden 2014.

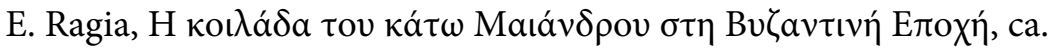

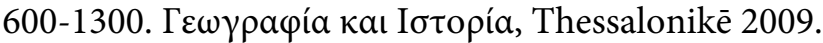

P. Scherrer, Von Apaša nach Hagios Theologos. Die Siedlungsgeschichte des Raumes Ephesos von prähistorischer bis in byzantinische Zeit unter dem Aspekt der maritimen und fluvialen Bedingungen, Jahreshefte des Österreichischen Archäologischen Institutes 76, 
Schliemann 1881

Steskal 2014

Stock e. a. 2013

Stock e. a. 2014

Telelis 2004

Telelis 2008

Thonemann 2011

Tok 2017

Trombley 1985

Veikou 2009

Veikou 2010

Veikou 2012a
2007, 321-351.

H. Schliemann, Reise in der Troas im Mai 1881. Mit einer Karte, Leipzig 1881.

M. Steskal, Ephesos and its Harbors: A City in Search of its Place, in: S. Ladstätter - F. Pirson - Th. Schmidts (Hgg.), Häfen und Hafenstädte im östlichen Mittelmeerraum von der Antike bis in byzantinische Zeit. Neue Entdeckungen und aktuelle Forschungsansätze. Harbors and Harbor Cities in the Eastern Mediterranean from Antiquity to the Byzantine Period: Recent Discoveries and Current Approaches, İstanbul, 30.5. - 1.6. 2011. I. Byzas 19, İstanbul 2014, 325-338.

F. Stock - A. Pint - B. Horejs - S. Ladstätter - H. Brückner, In search of the harbours: New evidence of Late Roman and Byzantine harbours of Ephesus, Quaternary International 312, 2013, 57-69.

F. Stock - M. Kerschner - J. C. Kraft - A. Pint - P. Frenzel - H. Brückner, The palaeogeographies of Ephesos (Turkey), its harbours, and the Artemision - a geoarchaeological reconstruction for the timespan 1500-300 BC., Zeitschrift für Geomorphologie 58, 2014, Suppl. 2, 33-66.

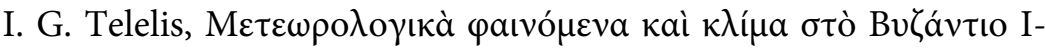
II, Athen 2004.

I. G. Telelis, Climatic Fluctuations in the Eastern Mediterranean and the Middle East AD 300-1500 from Byzantine Documentary and Proxy Physical Paleoclimatic Evidence: A Comparision, Jahrbuch der Österreichischen Byzantinistik 58, 2008, 167-207.

P. Thonemann, The Maeander Valley: A Historical Geography From Antiquity to Byzantium, Cambridge 2011.

E. Tok, Arvalya Basilica, in: A. Külzer - M. St. Popović (eds.), Space, Landscapes and Settlements in Byzantium: Studies in Historical Geography of the Eastern Mediterranean, Presented to Johannes Koder, Vienna-Novi Sad 2017, 373-384, 522-524.

F. R. Trombley, Paganism in the Greek World at the End of Antiquity: The Case of Rural Anatolia and Greece, Harvard Theological Review 78, 1985, 327-352.

M. Veikou, 'Rural Towns' and 'In-between Spaces': Settlement Patterns in Byzantine Epirus $\left(7^{\text {th }}-11^{\text {th }}\right.$ centuries) in an Interdisciplinary Approach, Archeologia Medievale 36, 2009, 43-54.

M. Veikou, Urban or Rural? Theoretical Remarks on the Settlement Patterns in Byzantine Epirus $\left(7^{\text {th }}-11^{\text {th }}\right.$ centuries), Byzantinische Zeitschrift 103, 2010, 171-193.

M. Veikou, Byzantine Epirus: A Topography of Transformation. Settlements from the $7^{\text {th }}$ to the $12^{\text {th }}$ centuries, Leiden-New York 
Veikou 2012b

Veikou 2013

Veikou 2016

Veikou, forthcoming

Veikou - Beihammer 2017

Whitby 1991
2012.

M. Veikou, Byzantine Histories, Settlement Stories: Kastra, 'Isles of Refuge' and 'Unspecified Settlements' as In-between or Third Spac-

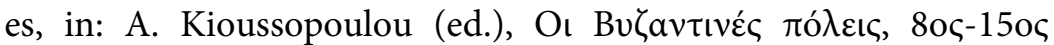
aı $\omega$ vac, Rethymno 2012, 159-206.

M. Veikou, Settlements in the Greek Countryside from the $4^{\text {th }}$ to the $9^{\text {th }}$ centuries: forms and patterns, Antiquité Tardive 21, 2013, 125133.

M. Veikou, Space in Texts and Space as Text: A new approach to Byzantine spatial notions, Scandinavian Journal of Byzantine and Modern Greek Studies 2, 2016, 143-176.

M. Veikou, The Reconstruction of Byzantine Lived Spaces: A Challenge for Survey Archaeology.

M. Veikou - A. Beihammer, 'Spatial' Identities: Literary Spaces and Human Agencies in Byzantine Smyrna through the Cartulary of Lembos Monastery (End of $12^{\text {th }}-13^{\text {th }}$ Centuries), in: A. Külzer $-M$. St. Popović (eds.), Space, Landscapes and Settlements in Byzantium: Studies in Historical Geography of the Eastern Mediterranean, Presented to Johannes Koder, Vienna-Novi Sad 2017, 385-406, 525.

M. Whitby, John of Ephesus and the Pagans: Pagan Survivals in the Sixth Century, in: M. Salamon (ed.), Paganism in the Later Roman Empire and in Byzantium, Cracow 1991, 111-131.

\section{Figures}

Fig. 1: Byzantine Province of Asia, QGIS 2.18 @ Andreas Külzer, 2018.

Fig. 2: Significant Changes of the Coast-line near Ephesus, Stock e. a. 2013, 58.

Fig. 3: The Ephesian Plain between Ayasoluk and Pamucak, () Andreas Külzer, 2016.

Fig. 4: The Hinterland of Ephesus, Hopfgartner 1962/1963, 68-69, revised. 


\section{Değișen Bir Bölgede Geçmişin Rekonstrüksiyonu. Efes Bölgesi ve Küçük Asya’nın Batısındaki Başka Bölgeler Hakkında Düşünceler Özet}

Peyzajlar daimi bir değişim içindedirler. Bu kısmen iklimsel değişimlerden veya tuzlanma örneğinde olduğu gibi toprak kalitesinin değişimleri gibi doğal nedenlerden olmakta, kısmen de ormanların yok edilmesi veya nehirlerin düzenlenmesi gibi insanlardan ve onların müdahalelerinden meydana gelmektedir. Diğerleri arasında, yerleşimlerin kuruluşu ve yolların yapılışı doğal bir yeri kültürel bir manzaraya dönüştürmek için olağan girişimlerdir. Tarihi coğrafya belli bir döneme, örnek olarak Geç Antik Dönem'e veya Orta Bizans Çağı'na odaklanarak bir peyzajın önceki halinin rekonstrüksiyonunu yapmaya çabalamaktadır. Rekonstrüksiyon çeşitli metotlar kullanarak - yani jeodezi ve jeofizik gibi bilimsel yaklaşımlarla birlikte yazılı kaynakların analizi veya arkeolojik bilgiler gibi tarihi veya filolojik yaklaşımlar - farklı bakış açılarına odaklanmaktadır. Farklı zaman kademeleri araştırma sonucu olarak sunulan resimde kendini gösterebilir; bazı yerler tarihleri boyunca çeşitli fikirler ve gelenekler ile bağlantılıdır. Bir akademik çalışmanın hem yazarı hem de okuyucusu taraflı yorumlamanın her tarihi ve tarihi coğrafik çalışmanın daima önemli bir etkeni olduğu gerçeğinin farkında olmalıdır. Batı Anadolu'daki başka yerlerin arasında Efes bölgesi şunu göstermek için iyi bir örnektir: Değişen bir peyzaj ve edebi kaynakların farklı yorumları ve yerel arkeolojik materyal bu bölgedeki Geç Antik Dönem ve Orta Çağ süresindeki yerleşim koşullarının farklı bir resmini sunmaktadir.

Anahtar Sözcükler: Ephesos; Geç Antikçă̆; Ortaçağ; Araştırma Metotları; Uzam.

\section{Reconstructing the Past in a changing Landscape. Reflections on the Area of Ephesus and other Sites in Western Asia Minor Abstract}

Landscapes are in perpetual transformation. This happens partly due to natural causes, like climatic changes or changes of soil quality, for example by salinization, partly due to human beings and their interventions, just to recall deforestation, or the regulation of rivers. Among others, the establishment of settlements and the construction of roads are common efforts to transform a natural space into a cultural landscape. - Historical geography tries to reconstruct the former state of a landscape, focusing on a special period, for example Late Antiquity or the Middle Byzantine Period. The reconstruction focus on different aspects, by using various methods, scientific approaches like geodesy and geophysics as well as historical or philological approaches like the analysis of written sources or archaeological data. Different time levels may appear in the picture presented as research result; some places are connected with diverse ideas and traditions during their history. Both the author and the reader of an academic study must be aware of the fact that subjective interpretation is always an important factor of each historical and historic-geographical work. Among other places in Western Anatolia, the area of Ephesus is a good example to illustrate this: a changing landscape and divergent interpretations of literary sources and the local archaeological material offer different pictures of the settlement conditions in that area during Late Antiquity and the Middle Ages.

Keywords: Ephesus; Late Antiquity; Middle Ages; research methods; space. 


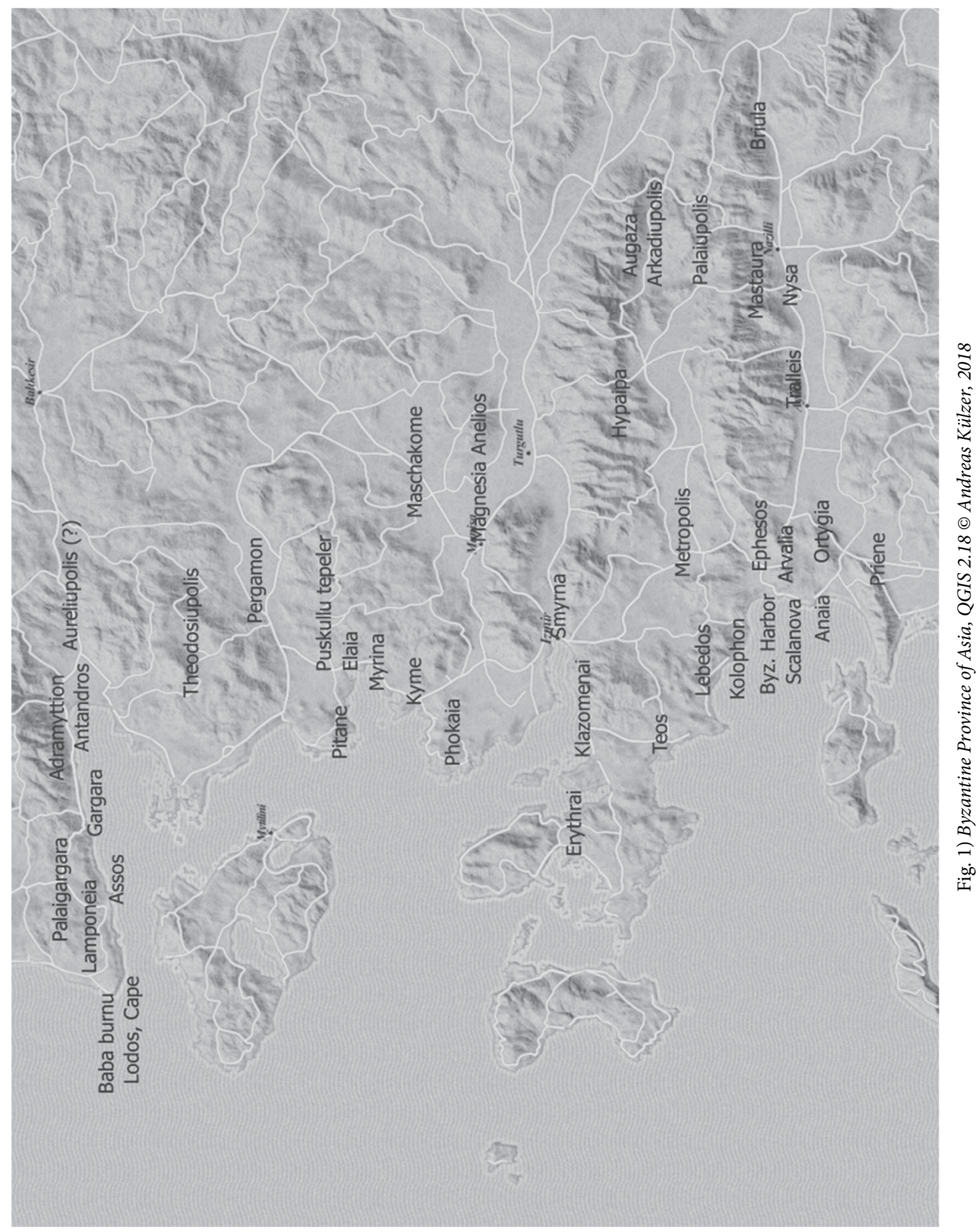




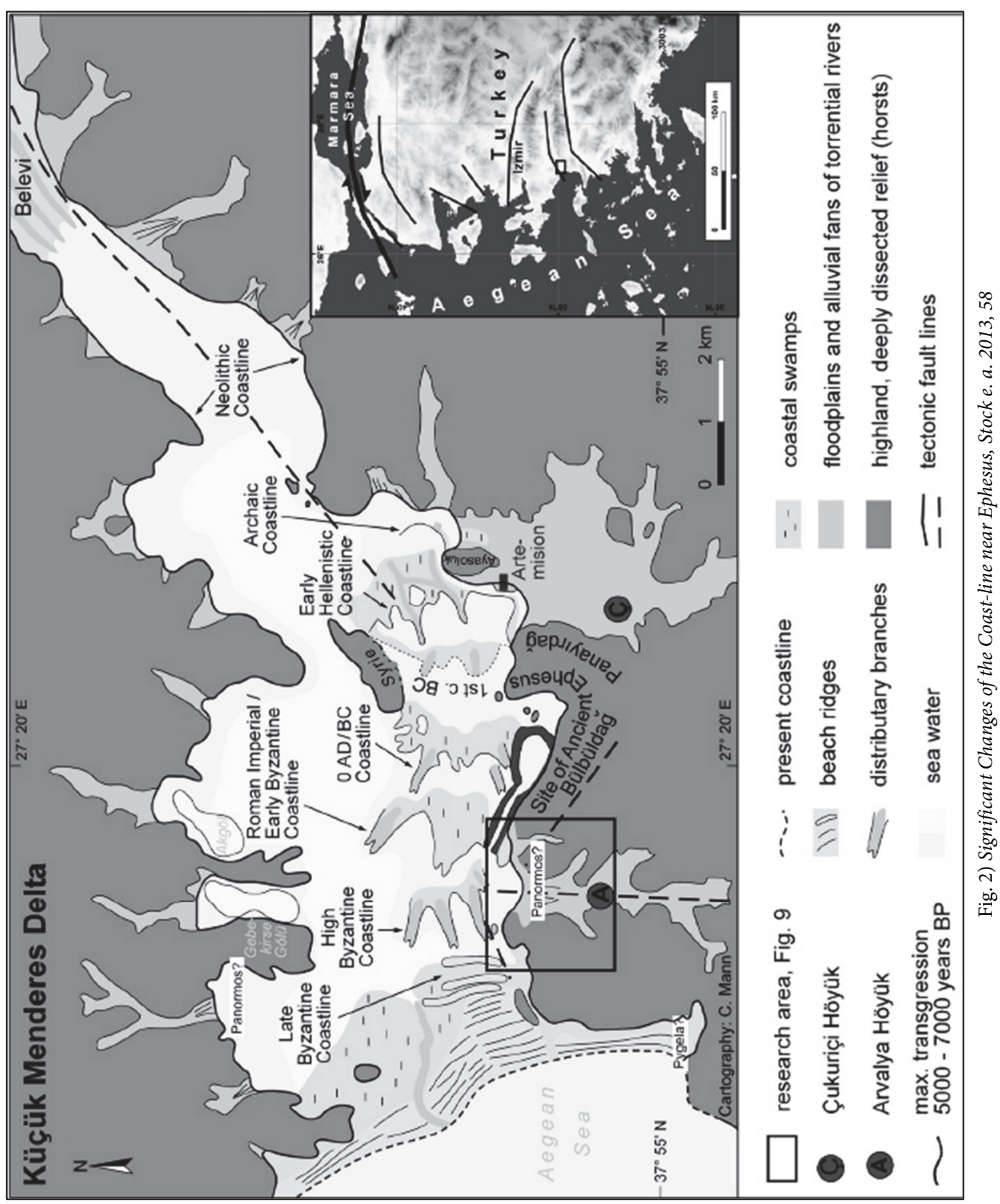



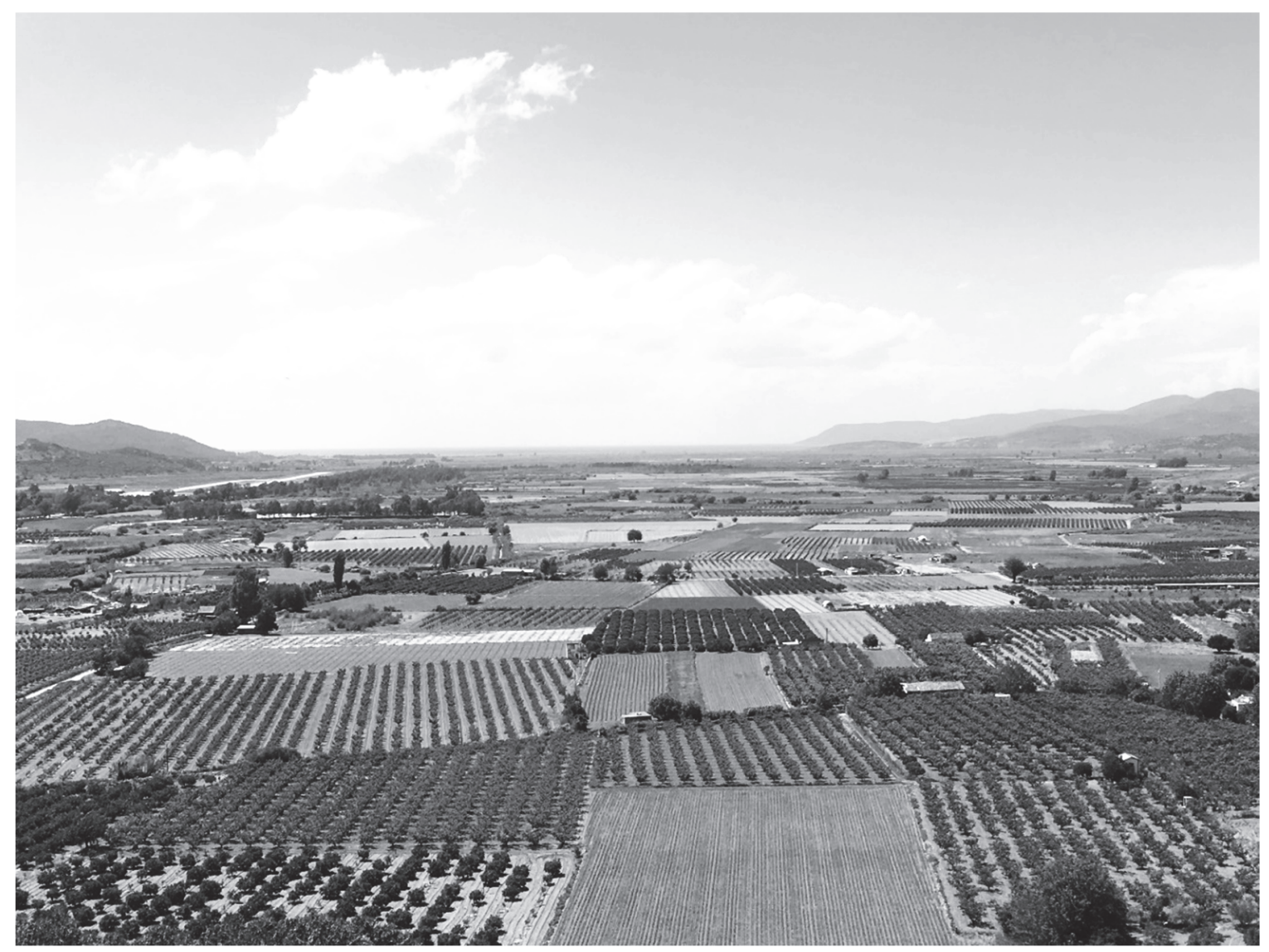

Fig. 3) The Ephesian Plain between Ayasoluk and Pamucak (@ Andreas Külzer, 2016)

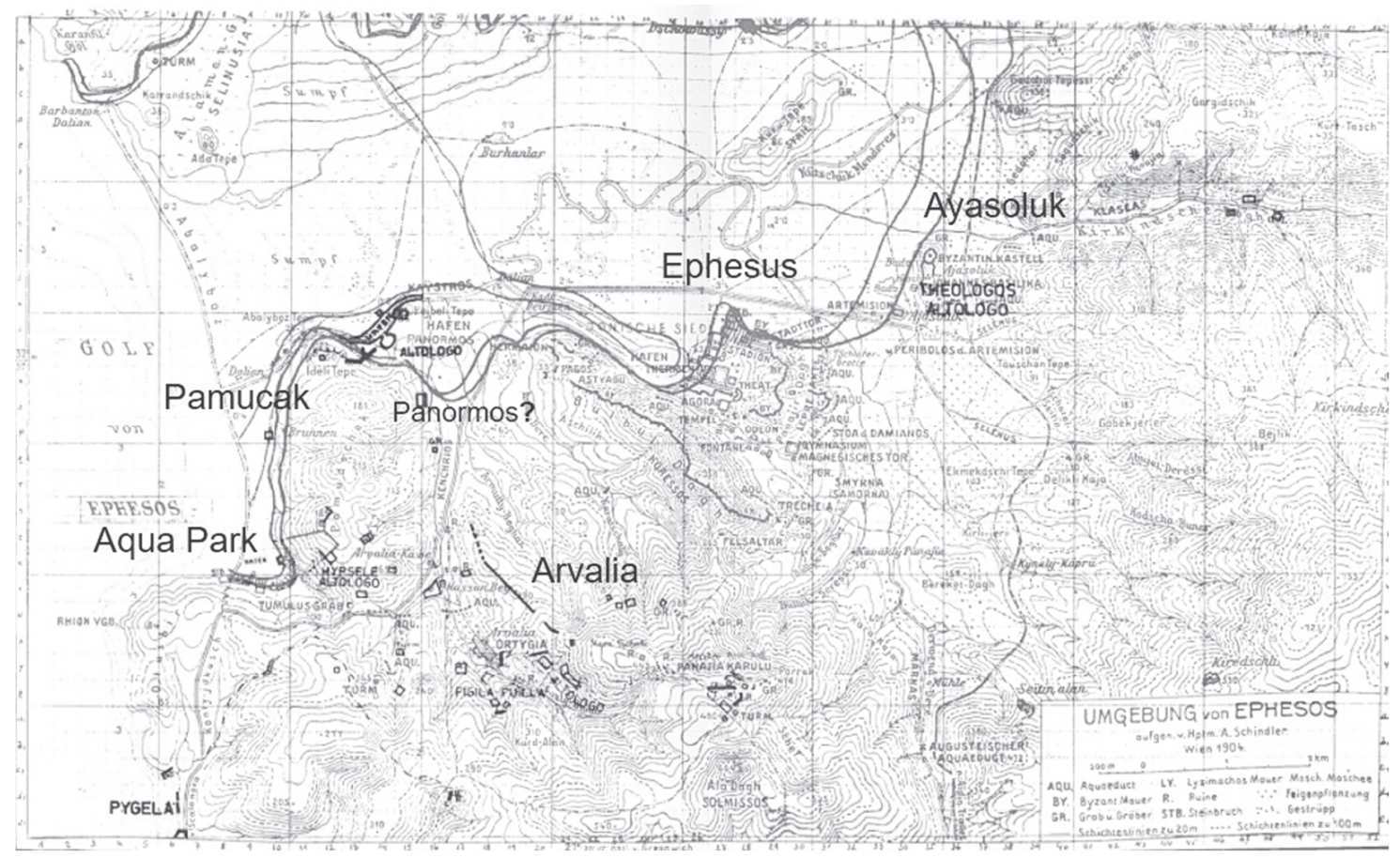

Fig. 4) The Hinterland of Ephesus, Hopfgartner 1962/1963, 68-69, revised 